\title{
Supply Chain Finance Factors: An Interpretive Structural Modeling Approach
}

\author{
Zericho R. Marak' ${ }^{1}$, Deepa Pillai ${ }^{2}$
}

Submitted: 18.03.2020. Accepted: 15.02.2021

\section{Abstract}

Purpose: The present study aims to identify the critical factors of supply chain finance and the interrelationship between the factors using interpretive structural modeling.

Methodology: Factors of supply chain finance were identified from the literature and experts from both industry and academia were consulted to assess the contextual relationships between the factors. Then, we applied interpretive structural modeling to examine the interrelationships between these factors and find out the critical factors.

Findings: The model outcome indicates information sharing and workforce to be the most influential factors, followed by the automation of trade and financial attractiveness.

Originality/value: Previous literature identified various factors that influence supply chain finance. However, studies showing interrelationships between these factors are lacking. This study is unique in the field as it applies total interpretive structural modeling for assessing the factors that affect supply chain finance. Our model will aid practitioners' decision-making and the adoption of supply chain finance by providing a necessary framework.

Keywords: supply chain finance, financial supply chain, interpretive structural modeling, factors, small and medium-sized enterprises.

JEL: G23, M10

Symbiosis International University, Symbiosis School of Banking and Finance, Lavale, Pune , Pune, Maharashtra 412115, India, zericho.marak@ssbf.edu.in; https://orcid.org/0000-0002-1478-6011.

2 Symbiosis International University, Symbiosis School of Banking and Finance, Lavale, Pune, Pune, Maharashtra 412115, India, deepa.pillai@ssbf.edu.in. 


\section{Introduction}

In 2008, the global economy witnessed a financial crisis affecting market liquidity and credit deployment of financial institutions, thereby restricting the overall credit growth of the economy. Traditional loan portfolios declined increasing firms' dependence on alternate sources of financing (Ivashina and Scharfstein, 2010). Moreover, the financial crisis aggravated the financial crunches faced by small and medium-sized enterprises (SMEs; Casey and O’Toole, 2014; Lee, Sameen, and Cowling, 2015). Supply chain finance (SCF) emerged to be of greater relevance after the financial crisis. Furthermore, the suitability of SCF to meet the financing needs of small and medium-sized enterprises (SMEs) that usually face difficulties in raising required funds, which contributed to the significance of SCF (Klapper, 2006; Marak and Pillai, 2019). Thus, SCF experienced a considerable growth rate with a compounded annual growth rate (CAGR) of 5\%, and experts expect it to experience a similar growth rate in the years to come (Sommer and O'Kelly, 2017). Supply chain finance outpaced the traditional trade finance market that occupies about half of the revenue pool of trade finance. Furthermore, at a global level, scholars estimate that there are USD 2 trillion financeable highly secured payables (Herath, 2015) and a trade finance gap of USD 1.5 trillion (Asian Development Bank, 2017), thereby indicating a massive opportunity that lies ahead for SCF (BSR, 2018).

Supply chain management comprises physical, informational, and financial flows. Previous studies on supply chain management concentrated on the physical and informational flow in the chain (Lamoureux and Evans, 2011; Caniato et al., 2016). However, to achieve effectiveness, efficiency, and competitiveness, scholars realized that the three components of SCF were equally essential, so they sought to align physical, informational, and financial flows that greatly contributed to the significance of SCF and ensuing studies.

Studies on SCF can be traced to the early 1970s. However, the concept of SCF lacked formal definition until the beginning of the 2000s (see Pfohl and Gomm, 2009; Xu et al., 2018). Supply chain finance is an inter-organizational optimization and the integration of financing processes to increase the value of all involved parties (Pfohl and Gomm, 2009). This includes financing and risk mitigation practices and techniques (Global Supply Chain Forum, n.d.). Supply chain finance is not limited only to working capital but may also include the financing of fixed assets (Gelsomino et al., 2016). There are multiple definitions and resulting perspectives of these definitions, while Gelsomino et al. (2016) find three perspectives on SCF: supply-chain-oriented, finance-oriented, and buyer-driven-oriented. The notion itself is an umbrella term that 
gathers multiple instruments/solutions (see Chakuu, Masi, and Godsell, 2019; Marak and Pillai, 2019).

The main aim of SCF is to optimize inter-firm financial flows, ideally through solutions offered by financial and technology service providers (Hofmann, 2005; Camerinelli, 2009; Lamoureux and Evans, 2011). According to Wuttke et al. (2013a), SCF ultimately aims to align financial flows with physical and financial flows, thus improving cash flow from the supply chain perspective.

Supply chain finance is influenced by several factors, so understanding the critical ones among them (see Marak and Pillai, 2019) is vital to the success and efficient application of SCF. This article seeks to identify SCF's influential factors and their interrelationships with the use of interpretive structural modeling (ISM). This is one of the first articles to explore the relationships between several factors that affect SCF with ISM. Besides, this study also shows the critical factors which can be improved in the implementation of SCF by the managers and practitioners belonging to a firm, its supply chain partners (suppliers and buyers), and even service providers.

\section{Literature Review}

The literature highlights several factors that influence the implementation and success of SCF. Some of the highly discussed factors are collaboration, the automation of trade processes, the digitalization of trade, trust, reputation, bargaining power, financial attractiveness, financing costs, information sharing, the availability of other external financing, the frequency and volume of transactions, and workforce (Marak and Pillai, 2019).

\section{Collaboration}

Supply chain finance involves collaborative means of improving the flow of funds, thus making collaboration a highly discussed factor in the literature (Blackman and Holland, 2006; Pfohl and Gomm, 2009; Hofmann and Belin, 2011; Popa, 2013; Wuttke et al., 2013b; Zhang, 2016; Protopappa-Sieke and Seifert, 2017). Collaboration is not only limited to inter-organizational activities but may also include interactions between departments of the same organization (Wandfluh et al., 2015; Caniato et al., 2016). 


\section{Trade Process Automation}

What also affects SCF is trade process automation or the level of digitalization. These help sharing information among involved parties, e.g. the firm, supplier, buyer, and financial service provider (Fairchild, 2005; Gomm, 2010; Wuttke et al., 2013b; Caniato et al., 2016; Chen, 2016; Hofmann et al., 2017; Ali et al., 2018; Zhou et al., 2018). The automation of trade processes may happen through enterprise resource planning (ERP), accounting packages, electronic invoicing, or enterprise data interchange (EDI; Camerinelli, 2009; Silvestro and Lustrato, 2014; Hofmann et al., 2017).

\section{Information Sharing}

Information sharing is crucial for supply chain effectiveness in general and SCF in particular. The concerned parties in SCF should make information available and share it with each other (Silvestro and Lustrato, 2014; Wandfluh et al., 2015; Jiang et al, 2016; Ding et al., 2017). Some of the important types of information to be shared in the supply chain are data that refer to inventory level, sales, sales forecasting, order status, production/delivery schedule, performance metrics, and capacity (Lee and Whang, 2000; Lotfi et al., 2013).

\section{Trust}

Trust is also crucial to the implementation of SCF, as two or more organizations are always involved in SCF. Moreover, trust should also accompany SCF instruments (Randall and Farris, 2009; Hofmann and Kotzab, 2010; Liebl et al., 2016; Martin, 2017). What contributes to building trust is h onesty and benevolence (Martin, 2017). Moreover, Iacono et al. (2015), Liebl et al. (2016), Chen (2016), and Zheng and Zhang (2017) discuss the importance of reputation and track record/image in supply chain financing.

\section{Bargaining Power}

Bargaining power of one party over the other may influence the use of SCF as it can affect the kind of SCF instruments use, e.g. terms and conditions (Hofmann and Kotzab, 2010; Caniato et al., 2016; Liebl et al., 2016; Wuttke et al., 2016; Chen et al., 2017; Protopappa-Sieke and Seifert, 2017; Wuttke et al., 2019). It is the capability of an organization to have an effect on the actions and intentions of another organization (Maloni and Benton, 2000). Other authors such as Martin (2017) and Wuttke et al. (2013b) study how the dependence of firms translates into the power of other SC partners involved in SCF. 


\section{Financial Attractiveness}

Caniato et al. (2016) use a multiple-case-based approach to posit that financial attractiveness influences the acceptance of SCF. The authors define financial attractiveness as the "attractiveness of the adopter as a potential market opportunity for a service provider" (Caniato et al., 2016, p. 541). This attractiveness may be due to the quality of receivables like factoring/receivables pledging (Sopranzetti, 1998; Soufani, 2002) or the saleability of inventories like inventory finance (Buzacott and Zhang, 2004; Li et al., 2011; Popa, 2013).

\section{Financing Cost}

Several studies argue that the cost of financing is crucial (Yan et al., 2014; Iacono et al., 2015; Babich and Kouvelis, 2018; Xiao and Zhang, 2018; Yu and Zhu, 2018). A firm and its supply chain partners would consider the financing cost while making decisions on raising funds through an SCF route. This cost of financing will refer to both SCF and non-SCF sources (Yan et al., 2014; Iacono et al., 2015; Babich and Kouvelis, 2018; Xiao and Zhang, 2018; Yu and Zhu, 2018).

\section{Availability of Other External Financing}

The availability of other external financing - i.e. non-SCF external financing - also influences the adoption of SCF. If financing options are wide for the firm, then SCF may seem unattractive (Martin, 2017; Chen and Kieschnick, 2018).

\section{Frequency and Volume of Transactions}

The use of SCF is also affected by the regularity and magnitude of transactions. Financial institutions and even supply chain partners may evaluate this frequency and volume of transactions before participating in SCF (Hofmann and Zumsteg, 2015; Iacono et al., 2015; Pellegrino et al., 2018).

\section{Workforce}

Moreover, SCF is influenced by the knowledge, skill, and expertise of the people in the organization and in the supply chain partnering organizations (Fairchild, 2005; Chen, 2016; Jiang et al., 2016). While studying the challenges in the adoption of SCF in the Indian context, More and Basu (2013) find human resource challenges to be 
one of the major barriers in the adoption of SCF. Table 1 offers a brief summary of these factors along with supporting sources.

\section{Table 1. Factors affecting supply chain finance}

\begin{tabular}{|c|c|c|}
\hline S.N. & Factor & Supporting References \\
\hline 1 & Collaboration & $\begin{array}{l}\text { Blackman and Holland (2006); Pfohl and Gomm (2009); Hofmann } \\
\text { and Belin (2011); Popa (2013); Wuttke et al. (2013b); Wandfluh et al. } \\
\text { (2015); Caniato et al. (2016); Zhang (2016); Protopappa-Sieke } \\
\text { and Seifert (2017) }\end{array}$ \\
\hline 2 & $\begin{array}{l}\text { Automation of trade } \\
\text { process }\end{array}$ & $\begin{array}{l}\text { Fairchild (2005); Gomm (2010); Wuttke et al. (2013a); Caniato et al. } \\
\text { (2016); Chen (2016); Hofmann et al. (2017); Ali et al. (2018); Zhou } \\
\text { et al. (2018) }\end{array}$ \\
\hline 3 & Trust & $\begin{array}{l}\text { Randall and Farris (2009); Hofmann and Kotzab (2010); Wuttke } \\
\text { et al. (2013a); Liebl et al. (2016); Martin (2017) }\end{array}$ \\
\hline 4 & Reputation & $\begin{array}{l}\text { lacono et al. (2015); Chen (2016); Liebl et al. (2016); Zheng } \\
\text { and Zhang (2017) }\end{array}$ \\
\hline 5 & Bargaining power & $\begin{array}{l}\text { Hofmann and Kotzab (2010); Wuttke et al. (2013b); Caniato et al. } \\
\text { (2016); Liebl et al. (2016); Wuttke et al. (2016); Chen et al. (2017); } \\
\text { Martin (2017); Protopappa-Sieke and Seifert (2017); Wuttke et al. } \\
\text { (2019) }\end{array}$ \\
\hline 6 & $\begin{array}{l}\text { Financial } \\
\text { attractiveness }\end{array}$ & $\begin{array}{l}\text { Sopranzetti (1998); Soufani (2002); Buzacott and Zhang (2004); } \\
\text { Li et al. (2011); Popa (2013); Caniato et al. (2016) }\end{array}$ \\
\hline 7 & Financing cost & $\begin{array}{l}\text { Yan et al. (2014); lacono, et al. (2015); Babich and Kouvelis (2018); } \\
\text { Xiao and Zhang (2018); Yu and Zhu (2018) }\end{array}$ \\
\hline 8 & Information sharing & $\begin{array}{l}\text { Silvestro and Lustrato (2014); Wandfluh, et al. (2015); Jiang et al. } \\
\text { (2016); Ding et al. (2017) }\end{array}$ \\
\hline 9 & $\begin{array}{l}\text { Availability of other } \\
\text { external financing }\end{array}$ & Martin (2017); Chen and Kieschnick (2018) \\
\hline 10 & $\begin{array}{l}\text { Frequency and volume } \\
\text { of transactions }\end{array}$ & $\begin{array}{l}\text { Hofmann and Zumsteg (2015); lacono, et al. (2015); Pellegrino et al. } \\
\text { (2018) }\end{array}$ \\
\hline 11 & Workforce & Fairchild (2005); More and Basu (2013); Chen (2016); Jiang et al. (2016) \\
\hline
\end{tabular}

Source: own elaboration.

\section{Research Methodology}

We identified factors of SCF from the comprehensive literature review. Subsequently, we consulted experts from industry and academia about the contextual relationships 
among the factors. Then, we employed interpretive structural modeling (ISM) to model the relationships among the factors and to determine the most influential factors.

\section{Interpretive Structural Modeling}

Interpretive structural modeling is a method that helps to generate solutions for complex problems through discourses based on structural mapping of interconnections of elements (Malone, 1975; Pfohl et al., 2011). ISM is a highly accepted and established method to uncover the relationships among elements that define a problem, and it is a modeling technique for examining the effect of one element on other elements (Agarwal et al., 2007; Attri et al., 2013; Al-Muftah et al., 2018). That is, ISM comprises nodes and links that depict a system's variable and direction of a relationship. The result of ISM is a model that shows the contextual relationships among its elements (Baykasoglu and Golcuk, 2017). ISM is widely used to study causal and hierarchical relationships among diverse factors (see Table 2).

\section{Table 2. Some papers applying ISM}

\begin{tabular}{|l|l|}
\hline \multicolumn{1}{|c|}{ Area of Study } & \multicolumn{1}{c|}{ Source/Authors } \\
\hline Factors influencing supply chain agility & Agarwal et al. (2007) \\
\hline Factors to enhance the competitiveness of SMEs & Singh et al. (2007) \\
\hline Identification of supply chain risks and their relationships & Pfohl et al. (2011) \\
\hline Evaluation of critical success factors (CSF) for ERP & Baykasoğlu and Gölcük (2017) \\
\hline Factors affecting the e-diplomacy implementation & Al-Muftah et al. (2018) \\
\hline Antecedents to innovation through Big Open Linked Data & Dwivedi et al. (2017) \\
\hline CSF for traceability of food logistics system & Shankar et al. (2018) \\
\hline Internal supply chain management benchmarking & Kailash et al. (2019) \\
\hline
\end{tabular}

Source: own elaboration.

Interpretive structural modeling follows a systematic methodology. The different steps involved in ISM - along with data analysis - are presented in Figure 1 and are explained in the following subsections: 
Figure 1. Interpretive structural model (ISM) flow chart

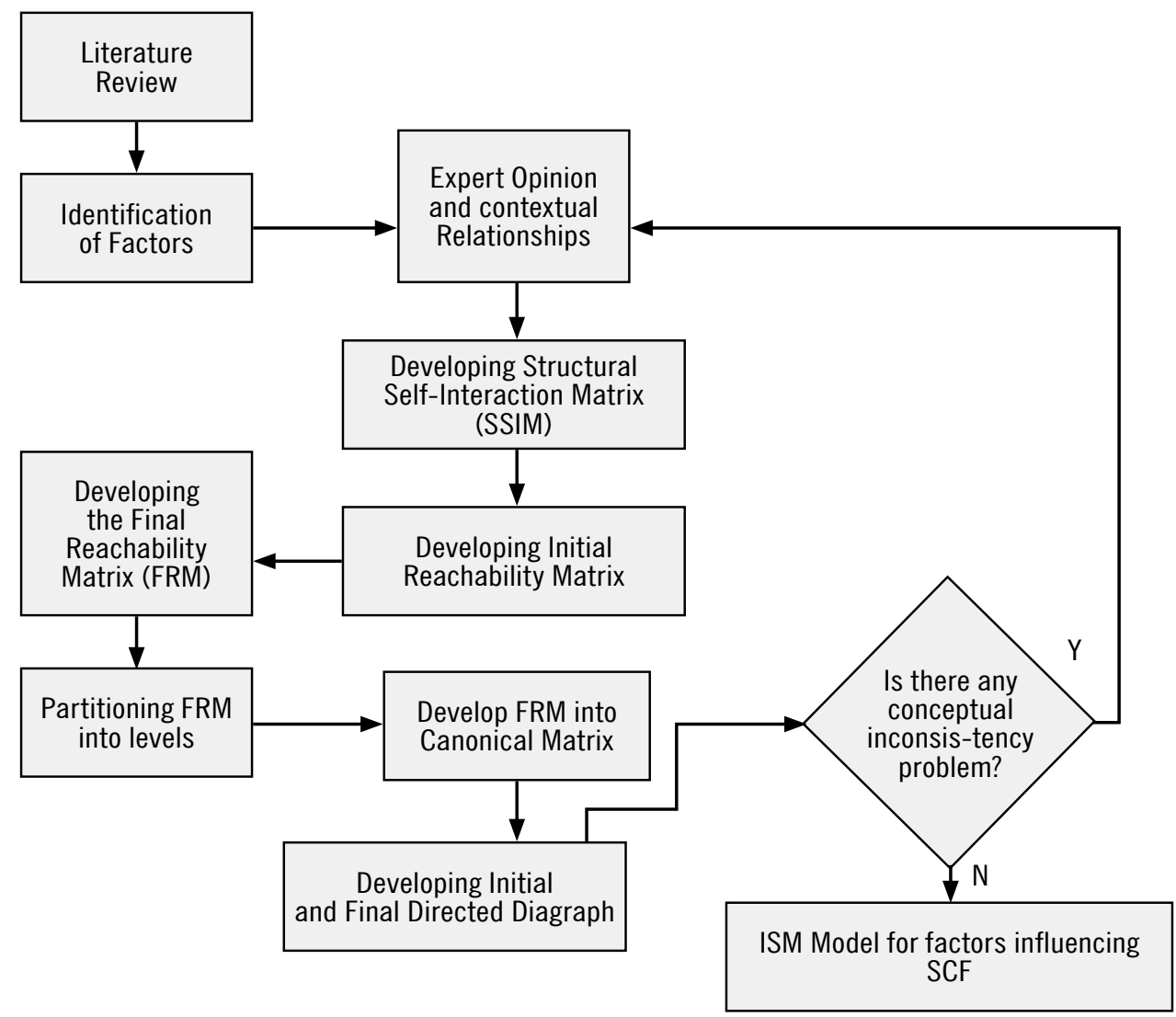

Source: own elaboration.

\section{Structural Self-Interaction Matrix (SSIM)}

At this stage, we established the contextual relationship between the two elements ( $i$ and $j$ ). Moreover, we examined the direction of the causal flow using SSIM, for which we employed four symbols to denote the directional relationship between elements $\mathrm{i}$ and $\mathrm{j}$ :

$\mathrm{V}$ - factor i will influence $\mathrm{j}$;

A - factor $j$ will influence $i$;

$\mathrm{X}$ - factors $\mathrm{i}$ and $\mathrm{j}$ influence each other;

$\mathrm{O}$ - factors $\mathrm{i}$ and $\mathrm{j}$ do not influence each other.

Based on experts' opinions, we formed the SSIM as depicted in Table 3. 
Table 3. Structural self-interaction matrix (SSIM)

\begin{tabular}{|c|c|c|c|c|c|c|c|c|c|c|c|}
\hline $\mathbf{i} / \mathbf{j}$ & 1 & 2 & 3 & 4 & 5 & 6 & 7 & 8 & 9 & 10 & 11 \\
\hline 1 & & $X$ & A & $X$ & V & 0 & V & $x$ & 0 & $x$ & $x$ \\
\hline 2 & & & V & V & V & V & V & $x$ & V & $X$ & $x$ \\
\hline 3 & & & & $X$ & V & 0 & 0 & $x$ & 0 & $X$ & $x$ \\
\hline 4 & & & & & V & V & 0 & 0 & $X$ & 0 & V \\
\hline 5 & & & & & & $A$ & V & 0 & $A$ & 0 & 0 \\
\hline 6 & & & & & & & V & $A$ & V & $x$ & 0 \\
\hline 7 & & & & & & & & 0 & A & $x$ & 0 \\
\hline 8 & & & & & & & & & 0 & 0 & V \\
\hline 9 & & & & & & & & & & 0 & 0 \\
\hline 10 & & & & & & & & & & & 0 \\
\hline 11 & & & & & & & & & & & \\
\hline
\end{tabular}

Source: own elaboration.

\section{Reachability Matrix}

Reachability matrix is a pair relationship of factors obtained through structural self-interaction matrix as developed in Table 3. At this stage, we focused on the development of the initial reachability matrix of SSIM, which is a binary matrix in which the entry $\mathrm{V}, \mathrm{A}, \mathrm{X}$, and $\mathrm{O}$ are transformed into binary numbers 0 and 1 on the basis of the following rules:

- If the (i, j) entry in the SSIM is V, then the $(i, j)$ is converted to 1 in initial reachability matrix and (j,i) entry is converted to 0 .

- If the (i, j) entry in the SSIM is A, then the (j,i) is converted to 1 in initial reachability matrix and $(i, j)$ entry is converted to 0 .

- If the (i, j) entry in the SSIM is X, then both (i,j) and (j,i) entries in initial reachability matrix are converted to 1 .

- If the (i, j) entry in the SSIM is O, then both (i,j) and (j,i) entries in reachability matrix are converted to 0 .

Table 4 shows the SSIM transformed into initial reachability matrix. 
Table 4. Initial reachability matrix

\begin{tabular}{|c|c|c|c|c|c|c|c|c|c|c|c|}
\hline $\mathrm{i} / \mathrm{j}$ & 1 & 2 & 3 & 4 & 5 & 6 & 7 & 8 & 9 & 10 & 11 \\
\hline 1 & 1 & 1 & 0 & 1 & 1 & 0 & 1 & 1 & 0 & 1 & 1 \\
\hline 2 & 1 & 1 & 1 & 1 & 1 & 1 & 1 & 1 & 1 & 1 & 1 \\
\hline 3 & 1 & 0 & 1 & 1 & 1 & 0 & 0 & 1 & 0 & 1 & 1 \\
\hline 4 & 1 & 0 & 1 & 1 & 1 & 1 & 0 & 0 & 1 & 0 & 1 \\
\hline 5 & 0 & 0 & 0 & 0 & 1 & 0 & 1 & 0 & 0 & 0 & 0 \\
\hline 6 & 0 & 0 & 0 & 0 & 1 & 1 & 1 & 0 & 1 & 1 & 0 \\
\hline 7 & 0 & 0 & 0 & 0 & 0 & 0 & 1 & 0 & 0 & 1 & 0 \\
\hline 8 & 1 & 1 & 1 & 0 & 0 & 0 & 0 & 1 & 0 & 0 & 1 \\
\hline 9 & 0 & 0 & 0 & 1 & 1 & 0 & 1 & 0 & 1 & 0 & 0 \\
\hline 10 & 1 & 1 & 1 & 0 & 0 & 1 & 1 & 0 & 0 & 1 & 0 \\
\hline 11 & 1 & 1 & 1 & 0 & 0 & 0 & 0 & 0 & 0 & 0 & 1 \\
\hline
\end{tabular}

Source: own elaboration.

\section{Final Reachability Matrix}

The final reachability matrix was formed on the basis of the assumption of transitivity, which is the basic assumption of ISM wherein element A is related to B, and B is related to $\mathrm{C}$, then $\mathrm{A}$ is related to $\mathrm{C}$. In the final reachability matrix, we also calculated the driving power and the dependence power (see Table 5).

Table 5. Final reachability matrix

\begin{tabular}{|c|c|c|c|c|c|c|c|c|c|c|c|c|}
\hline i/j & 1 & 2 & 3 & 4 & 5 & 6 & 7 & 8 & 9 & 10 & 11 & DRP \\
\hline 1 & 1 & 1 & $1^{*}$ & 1 & 1 & $1^{*}$ & 1 & 1 & $1^{*}$ & 1 & 1 & 11 \\
\hline 2 & 1 & 1 & 1 & 1 & 1 & 1 & 1 & 1 & 1 & 1 & 1 & 11 \\
\hline 3 & 1 & $1^{*}$ & 1 & 1 & 1 & $1^{*}$ & $1^{*}$ & 1 & $1^{*}$ & 1 & 1 & 11 \\
\hline 4 & 1 & $1^{*}$ & 1 & 1 & 1 & 1 & $1^{*}$ & $1^{*}$ & 1 & $1^{*}$ & 1 & 11 \\
\hline 5 & 0 & 0 & 0 & 0 & 1 & 0 & 1 & 0 & 0 & $1^{*}$ & 0 & 3 \\
\hline 6 & $1^{*}$ & $1^{*}$ & $1^{*}$ & $1^{*}$ & 1 & 1 & 1 & 0 & 1 & 1 & 0 & 9 \\
\hline 7 & $1^{*}$ & $1^{*}$ & $1^{*}$ & 0 & 0 & $1^{*}$ & 1 & 0 & 0 & 1 & 0 & 6 \\
\hline 8 & 1 & 1 & 1 & $1^{*}$ & $1^{*}$ & $1^{*}$ & $1^{*}$ & 1 & $1^{*}$ & $1^{*}$ & 1 & 11 \\
\hline
\end{tabular}




\begin{tabular}{|c|c|c|c|c|c|c|c|c|c|c|c|c|}
\hline 9 & $1^{*}$ & 0 & $1^{*}$ & 1 & 1 & $1^{*}$ & 1 & 0 & 1 & $1^{*}$ & $1^{*}$ & 9 \\
\hline 10 & 1 & 1 & 1 & $1^{*}$ & $1^{*}$ & 1 & 1 & $1^{*}$ & $1^{*}$ & 1 & $1^{*}$ & 11 \\
\hline 11 & 1 & 1 & 1 & $1^{*}$ & $1^{*}$ & $1^{*}$ & $1^{*}$ & $1^{*}$ & $1^{*}$ & $1^{*}$ & 1 & 11 \\
\hline DNP & 10 & 9 & 10 & 9 & 10 & 10 & 11 & 7 & 9 & 11 & 8 & 104 \\
\hline
\end{tabular}

* DRP and DNP signify “transitivity," Driving Power, and Dependence Power, respectively. Source: own elaboration.

\section{Partition of Final Reachability Matrix}

In the level partitioning of the final reachability matrix, we assessed the reachability set, the precursor set (i.e. antecedents), and intersection sets. The purpose of level partitioning was to assist in the construction of a diagram from the reachability matrix. The reachability set $\mathrm{R}\left(\mathrm{s}_{\mathrm{i}}\right)$ comprised both own and other elements that could reach from the element $\mathrm{s}_{\mathrm{i}}$. On the other hand, the antecedent set $\mathrm{A}\left(\mathrm{s}_{\mathrm{i}}\right)$ comprised own and other elements that could reach the element $s_{\mathrm{i}}$. The intersection set was the meeting point of the reachability set and the antecedent set, wherein the common elements between $\mathrm{R}\left(\mathrm{s}_{\mathrm{i}}\right)$, and antecedent set $\mathrm{A}\left(\mathrm{s}_{\mathrm{i}}\right)$ were present. The levels were fixed based on the common elements in the reachability and the intersection sets. When the factors showed similarity between reachability and intersection sets, they were ranked higher than other elements as these factors will not be driving other factors. Tables 6 to 9 show the level partitioning of the reachability matrix.

Table 6. Level partitioning of reachability matrix: iteration I

\begin{tabular}{|c|c|c|c|c|}
\hline $\begin{array}{c}\text { Element } \\
\left(s_{i}\right)\end{array}$ & $\begin{array}{c}\text { Reachability set: } \\
\qquad\left(s_{i}\right)\end{array}$ & $\begin{array}{l}\text { Antecedent set: } \\
\qquad A\left(s_{\mathrm{i}}\right)\end{array}$ & $\begin{array}{c}\text { Intersection set: } \\
R\left(s_{\mathrm{i}}\right) \& A\left(s_{\mathrm{i}}\right)\end{array}$ & Level \\
\hline 1 & $1,2,3,4,5,6,7,8,9,10,11$ & $1,2,3,4,6,7,8,9,10,11$ & $1,2,3,4,6,7,8,9,10,11$ & \\
\hline 2 & $1,2,3,4,5,6,7,8,9,10,11$ & $1,2,3,4,6,7,8,10,11$ & $1,2,3,4,6,7,8,10,11$ & \\
\hline 3 & $1,2,3,4,5,6,7,8,9,10,11$ & $1,2,3,4,6,7,8,9,10,11$ & $1,2,3,4,6,7,8,9,10,11$ & \\
\hline 4 & $1,2,3,4,5,6,8,9,10,11$ & $1,2,3,4,6,8,9,10,11$ & $1,2,3,4,6,8,9,10,11$ & \\
\hline 5 & $5,7,10$ & $1,2,3,4,5,6,8,9,10,11$ & $5,7,10$ & 1 \\
\hline 6 & $1,2,3,4,5,6,7,9,10$ & $1,2,3,4,6,7,8,9,10,11$ & $1,2,3,4,6,7,9,10$ & \\
\hline 7 & $1,2,3,6,7,10$ & $1,2,3,4,5,6,7,8,9,10,11$ & $1,2,3,6,7,10$ & I \\
\hline 8 & $1,2,3,4,5,6,7,8,9,10,11$ & $1,2,3,4,8,10,11$ & $1,2,3,4,8,10,11$ & \\
\hline 9 & $1,3,4,5,6,7,9,10,11$ & $1,2,3,4,6,8,9,10,11$ & $1,3,4,6,9,10,11$ & \\
\hline
\end{tabular}




\begin{tabular}{|l|l|l|l|}
$\mathbf{1 0}$ & $1,2,3,4,5,6,7,8,9,10,11$ & $1,2,3,4,5,6,7,8,9,10,11$ & $1,2,3,4,5,6,7,8,9,10,11$ \\
\hline $\mathbf{1 1}$ & $1,2,3,4,5,6,7,8,9,10,11$ & $1,2,3,4,8,9,10,11$ & $1,2,3,4,8,9,10,11$ \\
\hline
\end{tabular}

Source: own elaboration.

Table 7. Level partitioning of reachability matrix: iteration 2

\begin{tabular}{|c|c|c|c|c|}
\hline $\begin{array}{c}\text { Element } \\
\left(s_{i}\right)\end{array}$ & $\begin{array}{l}\text { Reachability set: } \\
\qquad \mathbf{R}\left(s_{\mathrm{i}}\right)\end{array}$ & $\begin{array}{l}\text { Antecedent set: } \\
\qquad A\left(s_{i}\right)\end{array}$ & $\begin{array}{l}\text { Intersection set: } \\
R\left(s_{i}\right) \& A\left(s_{i}\right)\end{array}$ & Level \\
\hline 1 & $1,2,3,4,6,8,9,11$ & $1,2,3,4,6,8,9,11$ & $1,2,3,4,6,8,9,11$ & II \\
\hline 2 & $1,2,3,4,6,8,9,11$ & $1,2,3,4,6,8,11$ & $1,2,3,4,6,8,11$ & \\
\hline 3 & $1,2,3,4,6,8,9,11$ & $1,2,3,4,6,8,9,11$ & $1,2,3,4,6,8,9,11$ & II \\
\hline 4 & $1,2,3,4,6,8,9,11$ & $1,2,3,4,6,8,9,11$ & $1,2,3,4,6,8,9,11$ & II \\
\hline 6 & $1,2,3,4,6,9$ & $1,2,3,4,6,8,9,11$ & $1,2,3,4,6,9$ & \\
\hline 8 & $1,2,3,4,6,8,9,11$ & $1,2,3,4,8,11$ & $1,2,3,4,8,11$ & \\
\hline 9 & $1,3,4,6,9,11$ & $1,2,3,4,6,8,9,11$ & $1,3,4,6,9,11$ & II \\
\hline 11 & $1,2,3,4,6,8,9,11$ & $1,2,3,4,8,9,11$ & $1,2,3,4,8,9,11$ & \\
\hline
\end{tabular}

Source: own elaboration.

Table 8. Level partitioning of reachability matrix: iteration 3

\begin{tabular}{|c|l|l|l|l|}
\hline $\begin{array}{c}\text { Element } \\
\left(\mathbf{s}_{\mathbf{i}}\right)\end{array}$ & \multicolumn{1}{|c|}{$\begin{array}{c}\text { Reachability set: } \\
\mathbf{R}\left(\mathbf{s}_{\mathbf{i}}\right)\end{array}$} & $\begin{array}{c}\text { Antecedent set: } \\
\mathbf{A}\left(\mathbf{s}_{\mathbf{i}}\right)\end{array}$ & \multicolumn{1}{|c|}{$\begin{array}{c}\text { Intersection set: } \\
\mathbf{R}\left(\mathbf{s}_{\mathbf{i}}\right) \mathbf{\&} \mathbf{A}\left(\mathbf{s}_{\mathbf{i}}\right)\end{array}$} & Level \\
\hline $\mathbf{2}$ & $2,6,8,11$ & $2,6,8,11$ & $2,6,8,11$ & III \\
\hline $\mathbf{6}$ & 2,6 & $2,6,8,11$ & 2,6 & \\
\hline $\mathbf{8}$ & $2,6,8,11$ & $2,8,11$ & $2,8,11$ & \\
\hline $\mathbf{1 1}$ & $2,6,8,11$ & $2,8,11$ & $2,8,11$ & \\
\hline
\end{tabular}

Source: own elaboration.

Table 9. Level partitioning of reachability matrix: iteration 4

\begin{tabular}{|c|c|c|c|c|}
$\begin{array}{c}\text { Element } \\
\left(\mathbf{s}_{\mathbf{i}}\right)\end{array}$ & $\begin{array}{c}\text { Reachability set: } \\
\mathbf{R}\left(\mathbf{s}_{\mathbf{i}}\right)\end{array}$ & $\begin{array}{c}\text { Antecedent set: } \\
\mathbf{A}\left(\mathbf{s}_{\mathbf{i}}\right)\end{array}$ & $\begin{array}{c}\text { Intersection set: } \\
\mathbf{R}\left(\mathbf{s}_{\mathbf{i}}\right) \mathbf{\&} \mathbf{A}\left(\mathbf{s}_{\mathbf{i}}\right)\end{array}$ & Level \\
\hline $\mathbf{8}$ & 8.11 & & 8.11 & 8.11 \\
\hline $\mathbf{1 1}$ & 8.11 & 8.11 & 8.11 & IV \\
\hline
\end{tabular}

Source: own elaboration. 


\section{Canonical Matrix}

The canonical matrix was prepared for variables in the same level grouped together based on the outcome of the final reachability matrix (see Table 10).

\section{Table 10. Canonical matrix}

\begin{tabular}{|c|c|c|c|c|c|c|c|c|c|c|c|}
\hline $\begin{array}{c}\text { Element } \\
\left(s_{i}\right)\end{array}$ & 1 & 2 & 3 & 4 & 5 & 6 & 7 & 8 & 9 & 10 & 11 \\
\hline 5 & 0 & 0 & 0 & 0 & 1 & 0 & 1 & 0 & 0 & 1 & 0 \\
\hline 7 & 1 & 1 & 1 & 0 & 0 & 1 & 1 & 0 & 0 & 1 & 0 \\
\hline 10 & 1 & 1 & 1 & 1 & 1 & 1 & 1 & 1 & 1 & 1 & 1 \\
\hline 1 & 1 & 1 & 1 & 1 & 1 & 1 & 1 & 1 & 1 & 1 & 1 \\
\hline 3 & 1 & 1 & 1 & 1 & 1 & 1 & 1 & 1 & 1 & 1 & 1 \\
\hline 4 & 1 & 1 & 1 & 1 & 1 & 1 & 1 & 1 & 1 & 1 & 1 \\
\hline 9 & 1 & 0 & 1 & 1 & 1 & 1 & 1 & 0 & 1 & 1 & 1 \\
\hline 2 & 1 & 1 & 1 & 1 & 1 & 1 & 1 & 1 & 1 & 1 & 1 \\
\hline 6 & 1 & 1 & 1 & 1 & 1 & 1 & 1 & 0 & 1 & 1 & 0 \\
\hline 8 & 1 & 1 & 1 & 1 & 1 & 1 & 1 & 1 & 1 & 1 & 1 \\
\hline 11 & 1 & 1 & 1 & 1 & 1 & 1 & 1 & 1 & 1 & 1 & 1 \\
\hline
\end{tabular}

Source: own elaboration.

\section{Developing the Diagram}

Based on the canonical matrix and final reachability matrix, we formed the initial diagram of factors influencing SCF. The final diagram was developed after removing indirect links. Figure 2 shows the final ISM-based model of factors influencing SCF.

Information sharing (8) and workforce (11) occupy the lowest level of the hierarchy (level IV) in the ISM-based model, which shows them as the most important factors that drive all other factors. These two (8 and 11) reveal that the availability and sharing of information among parties involved in the SCF are crucial for its implementation. Equally important is the knowledge, skill, and expertise of the people in the organization and partnering firms. Without proper and capable human resources, the adoption and success of SCF will suffer. The automation of trade process (2) and financial attractiveness (6) occupy level III in the hierarchy. The factors in the level II category are collaboration (1), trust (2), reputation (4), and the availability of other external financing (9). These factors are more dependent and have a lower driving power than 
the first two levels (i.e. level IV and III factors). Level I factors, bargaining power (5), financing cost (7), and the frequency and volume of transactions (10) have maximum dependence and the least driving power as compared to the factors in former levels (i.e. level IV, III, and II). These factors are highly dependent on the factors from the other levels.

Figure 2. ISM based model of factors influencing SCF

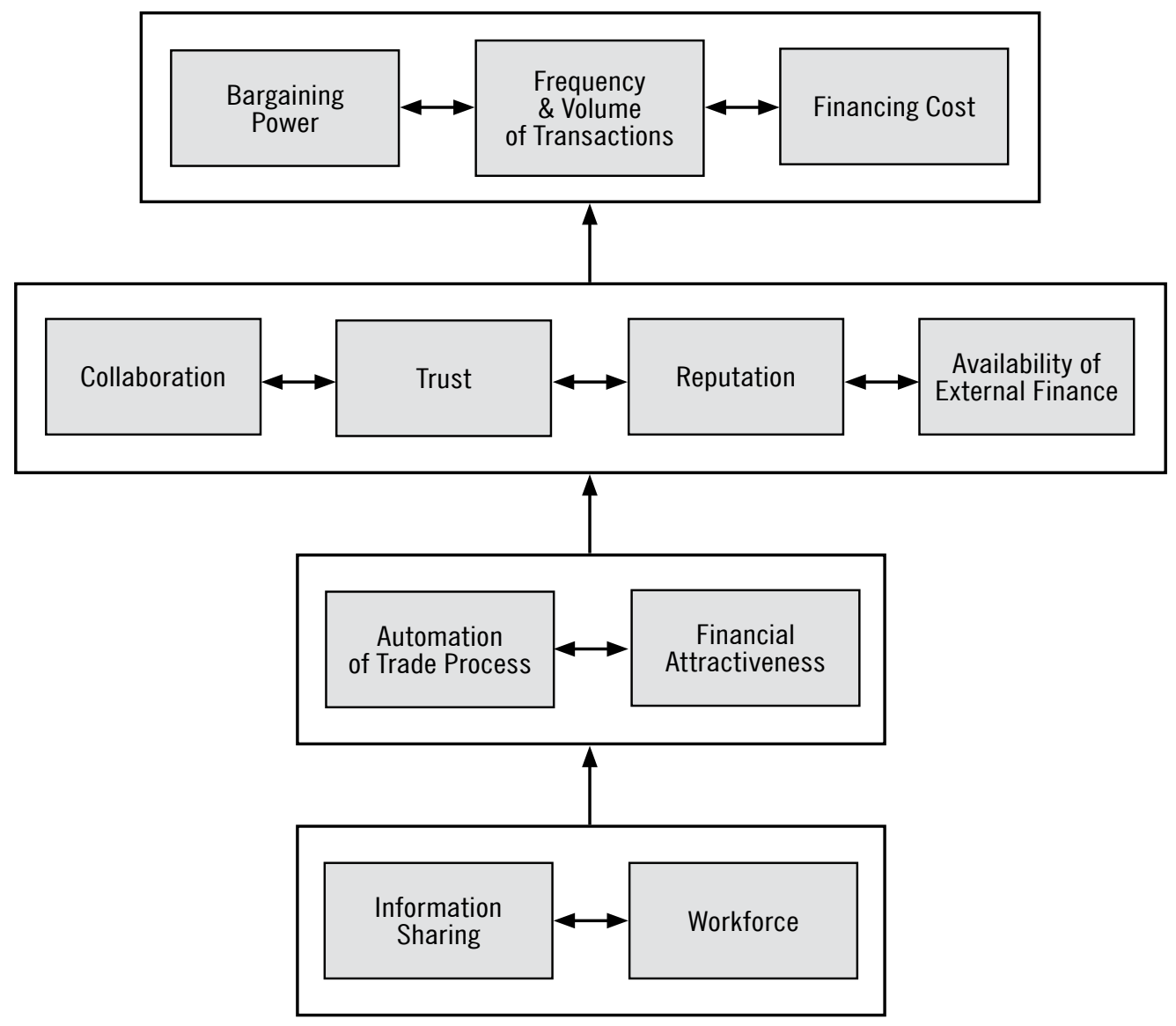

Source: own elaboration.

\section{MICMAC Analysis}

Matrice d'impacts croisés multiplication appliquée á un classment (MICMAC), a cross-impact matrix multiplication applied to classification, is a structural prospective analysis used to study indirect relationships (Saxena et al., 1990; Ahmad et al., 
2019). The MICMAC method of analysis was developed by Duperrin and Godet (Chandramowli et al., 2011). In this study, the MICMAC analysis was used to classify the factors that influence SCF based on driving and dependence power. The method served the purpose of validating the results of ISM by helping in the critical analysis of the scope of each element. For that purpose, we formed groups: autonomous factors, dependent factors, linkage factors, and independent factors (Mandal and Deshmukh, 1994; Agarwal et al., 2007).

Figure 3. Driving power and dependence power diagram

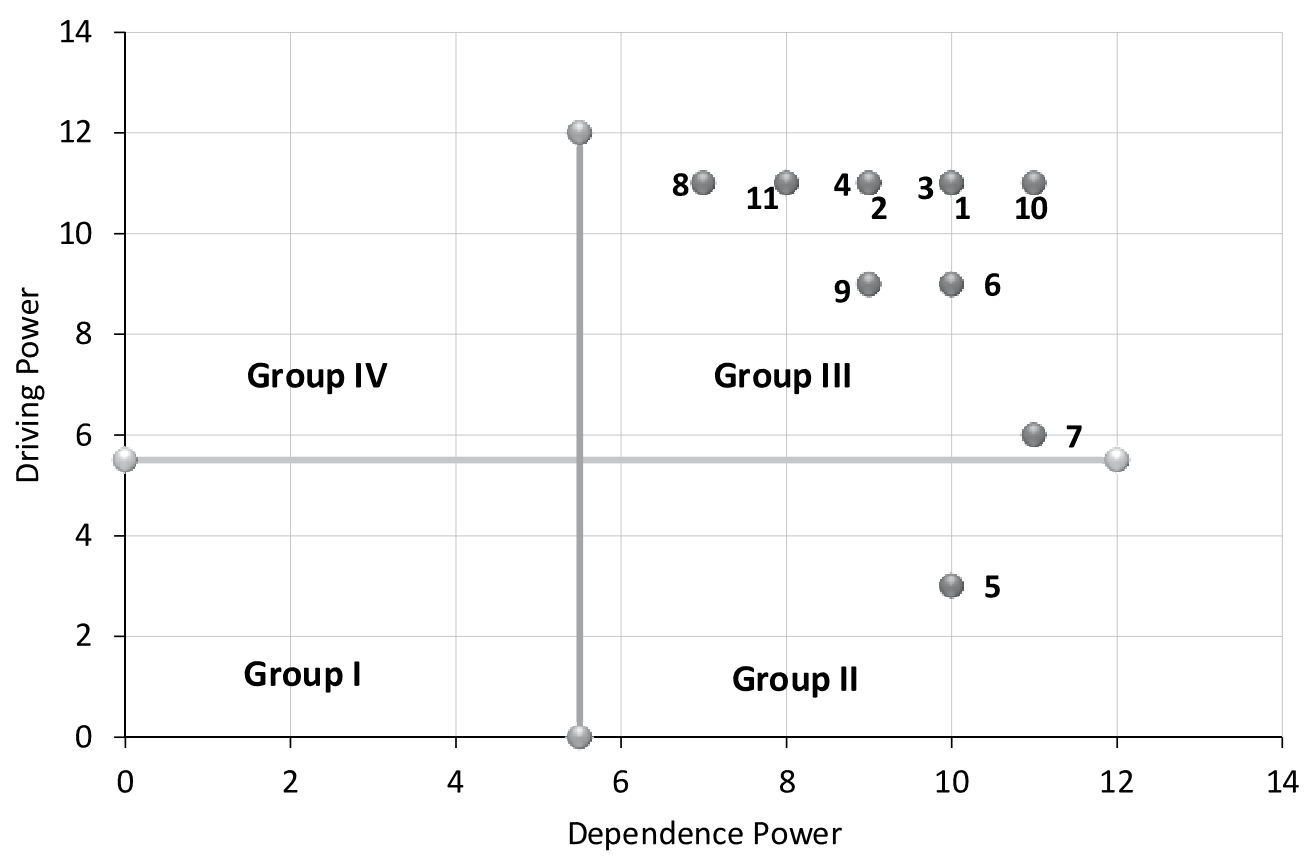

Source: own elaboration.

Group I (Autonomous) contained the autonomous factors with weak driving and dependence powers. Group II (Dependent) included dependent elements with weak driving and strong dependence powers. Group III (Linkage) contained linkage factors with strong driving and dependence powers. Lastly, Group IV (Independent) contained driver factors with strong driving and weak dependence powers. Figure 3 shows the factors that influence SCF classified based on driving and dependence power. Bargaining power (5) emerged in Group II, meaning it was a dependent factor. The majority of variables appeared in Group III (Linkage Factor), wherein the dependence power and driving power are both strong and affect each other. No factor appeared in Group I, which consists of factors disconnected from the rest. Surprisingly, also no factor 
appeared in Group IV, which contains those high in driving power and low in dependence power. Even the factors such as information sharing (8) and workforce (11) - whose dependence was lower compared to the rest - were grouped in the linkage factor. The in the MICMAC analysis showed that all the factors have strong interrelationships with each other.

\section{Discussion and Conclusion}

Supply chain finance has gained importance recently due to such reasons as the earlier neglect of financial flows of the supply chain and the reduction of bank loans after the financial crisis that would be suitable to service the financing needs of SMEs. Our study identified the factors from the literature and explored the relationships among these factors. For this, we sought expert opinions from both the industry and academia, after which we developed the ISM-based model.

The ISM-based model showed the highest level (level I) in its hierarchy to be occupied by bargaining power, financing cost, and the frequency and volume of transactions. These variables have the lowest driving power and are highly dependent on other factors. Several authors report that these variables influence SCF (Wuttke et al., 2013a; Yan et al., 2014; Iacono et al., 2015; Caniato et al., 2016; Liebl et al., 2016). These factors depend on variables such as collaboration, trust, reputation, and the availability of other external financing (level II; Randall and Farris, 2009; Hofmann and Kotzab, 2010; Iacono et al., 2015; Liebl et al., 2016; Martin, 2017; Protopappa-Sieke and Seifert, 2017). Trust and collaboration between supply chain partners can lead to an increase in transactions, which can result in a reduction in costs and improvement in financial performance. Although trust in a relationship can be affected by the degree of power between the parties (Farrell, 2004; Ando and Rhee, 2009), it may also influence the power itself as when one party trusts the other there may be no need to control the behavior of the other party (Inkpen and Currall, 2004). Similarly, the collaboration between the supply chain partners can result in a decrease in the exercise of power and control by one of the partners (Simatupang, Wright, and Sridharan, 2004). Similarly, a firm's reputation or goodwill may also have a bearing on transactions between the parties. Studies show that reputation can offer a strategic advantage to the firm and introduce superior performance (Roberts, 2003). The availability of other sources of external financing influences the cost of financing through the SCF route. Thus, SCF will be attractive only if one of the SCF partners - e.g. the supplier - has access to external financing at a higher cost (Martin, 2017). Generally, SCF should help in reducing the cost of financing as it may influence either one or more dimensions of the supply chain 
finance cube, i.e. the cost of capital rate, duration, and volume (Pfohl and Gomm, 2009). Besides, access to external financing will also affect the frequency and volume of transactions between the trading partners. Lesser access to other external financing by one of the trading partners is expected to lead to more dependence and hence more transactions between the parties (Martin, 2017). The level III variables - i.e. the automation of trade and financial attractiveness - influence the level II variables. The influence of these on SCF can be observed in the literature (Buzacott and Zhang, 2004; Blackman and Holland, 2006; Popa, 2013; Wuttke et al., 2013; Caniato et al., 2016). The automation of trade - meaning technology - can play a key role in improving trust and collaboration between the trading partners (Lee and Gao, 2005; Angerhofer and Angelides, 2006; Crook et al., 2008; Lee, Palekar, and Qualls, 2011; Hudnurkar, Jakhar, and Rathod, 2014). Having a sound technology could help in establishing a good reputation among the supply chain partners. Moreover, it could help in reducing information asymmetry between them by having a bearing on the availability of other external financing. Resources contribute to the financial attractiveness of a firm (Caniato et al., 2016). Previous studies show that resource sharing among supply chain partners enhances trust and collaboration (Ye and Zhang, 2010; Zhang and Huo, 2013; Hudnurkar et al., 2014). Firm resources can help in securing a good reputation and availing external financing as well (Gynther, 1969; Greyser, 1999). The lowest level (level IV) variables are information sharing and workforce. These variables are considered to be strong drivers of SCF (Fairchild, 2005; Silvestro and Lustrato, 2014; Wandfluh et al., 2015; Chen, 2016; Jiang et al., 2016) as they influence other factors through the automation of trade and financial attractiveness. The recognition of the need or desire for a particular kind of information may lead to the choice of information technology. Information is vital in enhancing the financial attractiveness of a firm as non-transparency or the asymmetry of information can act as a hindrance in availing financing (Shinozaki, 2014). The knowledge, skill, and expertise of a firm - along with the partnering firm - will have a bearing on the automation or digitalization of trade. For the technology to be seamless, it should be properly integrated with the supply chain partners. Theories involving innovation adoption also discuss the significance of people in the implementation and diffusion of innovation at the organizational level (Davis, 1989; Rogers, 2010).

Finally, we performed the MICMAC analysis, which showed that none of the variables under scrutiny is autonomous while all the factors are highly interconnected with each other. 


\section{Managerial Implications}

This study will have implications for managers and owners of firms and partnering firms (mostly SMEs) whereby they can concentrate on influential factors, particularly information sharing, workforce, the automation of trade process, and financial attractiveness. This will help them improve the implementation of SCF, increase its effectiveness, and ensure its maximum benefits. Managers should focus on information sharing in the organization and with supply chain partners. This information could pertain to sales data, sales forecast, inventory level/policy, order status, production, or delivery schedule. To improve workforce knowledge and skill, managers could provide it with the necessary orientation, training, and development. Several parties could also take the responsibility of providing such an orientation, training, and development, e.g. associations and chambers to which a firm/supply chain partners belong, larger organizations in the supply chain, government authorities, or policy-makers that work on improving entrepreneurship and SMEs, and even financial/technology services providers. A firm and its supply chain partners should focus on the automation or digitalization of trade processes. Managers should concentrate on the compatibility, interoperability, and integration of digitalization across the supply chain for enhancing effectiveness and efficiency in the facilitation of SCF. Financial attractiveness is important, particularly in the case of financial service provider mediated SCF. However, what can be of immense benefits for organizations - especially for SMEs - is understanding that e.g. the quality of receivables, purchase orders, and the saleability of inventories can serve as underlying assets (instead of other assets as collaterals or pledging personal wealth) against which financing can be availed in SCF.

Furthermore, understanding the relationship between the SCF factors could help the firm and its supply chain partners in managing working capital from the collaborative supply chain perspective rather than from a single organization perspective. Firms and financial managers tend to maximize their financial gains at the cost of supply chain partners while approaching working capital from a single organizational perspective. As such, firms may resort to actions such as delaying payments, extending credit periods to their suppliers, minimizing credit periods to their customers, or aggressive recovery policies. These actions can increase the overall cost, risk, and disruption in a supply chain. Such behaviors of firms can be observed more apparently during economic downturns, e.g. the global financial crisis of 2008, when banks and financial institutions frequently decline loans. The goal of firms and financial managers should be to create a win-win situation for all the engaged parties, which SCF can create. An understanding of the factors and their interlinkages will also help the financial/technology services providers in improving the facilitation of SCF solutions/technology. 


\section{Study Limitations}

The main limitation of our study is that the model and subsequent results base on the opinions of experts. Although we sought to include experts from both the industry and academia, the results are limited to their knowledge and perceptions. Thus, the findings may not be generalizable.

\section{Future Research}

This study may be further extended by collecting larger data sets by using survey methods from the field or building a model with structural equation modeling (SEM). However, we suggest that future studies concentrate on such parameters as size (be it SMEs or large enterprises) or industry/sector. Moreover, it would be interesting to perform system dynamics modeling with these factors so as to understand the behavior of these factors and their effect on SCF.

\section{References}

Ahmad, M., Tang, X.W., Qiu, J.N., and Ahmad, F. (2019). Interpretive structural modeling and MICMAC analysis for identifying and benchmarking significant factors of seismic soil liquefaction. Applied Sciences, 9(2), 233. https://doi.org/10.3390/app9020233.

Ando, N., and Rhee, D.K. (2009). Antecedents of interorganizational trust: joint decision-making, cultural adaptation, and bargaining power. Journal of Asia Business Studies, 3(2), 16-29. https://doi.org/10.1108/15587890980001513.

Angerhofer, B.J., and Angelides, M.C. (2006). A model and a performance measurement system for collaborative supply chains. Decision Support Systems, 42(1), 283-301.

https://doi.org/10.1016/j.dss.2004.12.005.

Agarwal, A., Shankar, R., and Tiwari, M.K. (2007). Modeling agility of supply chain. Industrial marketing management, 36(4), 443-457. https://doi.org/10.1016/j.indmarman.2005.12.004.

Ali, Z., Gongbing, B., and Mehreen, A. (2018). Does supply chain finance improve SMEs performance? The moderating role of trade digitization. Business Process Management Journal. https://doi.org/10.1108/BPMJ-05-2018-0133.

Al-Muftah, H., Weerakkody, V., Rana, N.P., Sivarajah, U., and Irani, Z. (2018). Factors influencing e-diplomacy implementation: Exploring causal relationships using interpretive structural modelling. Government Information Quarterly, 35(3), 502-514.

https://doi.org/10.1016/j.giq.2018.03.002

Asian Development Bank (2017). Trade Finance Gaps, Growth, and Jobs Survey.

Attri, R., Dev, N., and Sharma, V. (2013). Interpretive structural modelling (ISM) approach: an overview. Research Journal of Management Sciences, 2(2), 3-8.

Babich, V., and Kouvelis, P. (2018). Introduction to the special issue on research at the interface of finance, operations, and risk management (iFORM): Recent contributions and future directions. Manufacturing \& Service Operations Management, 20, 1-160.

https://doi.org/10.1287/msom.2018.0706 
Baykasoğlu, A., and Gölcük, İ. (2017). Development of a two-phase structural model for evaluating ERP critical success factors along with a case study. Computers \& Industrial Engineering, 106, 256-274. https://doi.org/10.1016/j.cie.2017.02.015.

Blackman, I.D., and Holland, C. (2006). The management of financial supply chains: from adversarial to co-operative strategies. In: Project E-Society: Building Bricks (pp. 82-95). Springer, Boston, MA. https://doi.org/10.1007/978-0-387-39229-5_8.

BSR. (2018). Win-Win-Win: The Sustainable Supply Chain Finance Opportunity, 2019.

Buzacott, J.A., and Zhang, R.Q. (2004). Inventory management with asset-based financing. Management Science, 50(9), 1274-1292. https://doi.org/10.1287/mnsc.1040.0278.

Camerinelli, E. (2009). Supply chain finance. Journal of Payments Strategy \& Systems, 3(2), 114-128.

Caniato, F., Gelsomino, L.M., Perego, A., and Ronchi, S. (2016). Does finance solve the supply chain financing problem? Supply Chain Management: An International Journal, 21(5), 534-549. https://doi.org/10.1108/SCM-11-2015-0436.

Casey, E., and O’Toole, C.M. (2014). Bank lending constraints, trade credit and alternative financing during the financial crisis: Evidence from European SMEs. Journal of Corporate Finance, 27, 173-193. https://doi.org/10.1016/j.jcorpfin.2014.05.001.

Chakuu, S., Masi, D., and Godsell, J. (2019). Exploring the relationship between mechanisms, actors and instruments in supply chain finance: A systematic literature review. International Journal of Production Economics, 216, 35-53. https://doi.org/10.1016/j.ijpe.2019.04.013.

Chandramowli, S., Transue, M., and Felder, F.A. (2011). Analysis of barriers to development in landfill communities using interpretive structural modeling. Habitat International, 35(2), 246-253. https://doi.org/10.1016/j.habitatint.2010.09.005.

Chen, Q. (2016). A Supply Chain Financial Service Management Model of Chinese Logistics Enterprises. International Journal of Simulation Systems, Science \& Technology, 17.

Chen, C., and Kieschnick, R. (2018). Bank credit and corporate working capital management. Journal of Corporate Finance, 48, 579-596. https://doi.org/10.1016/j.jcorpfin.2017.12.013.

Chen, J., Zhou, Y.W., and Zhong, Y. (2017). A pricing/ordering model for a dyadic supply chain with buyback guarantee financing and fairness concerns. International Journal of Production Research, 55(18), 5287-5304. https://doi.org/10.1080/00207543.2017.1308571.

Crook, T.R., Giunipero, L., Reus, T.H., Handfield, R., and Williams, S.K. (2008). Antecedents and outcomes of supply chain effectiveness: an exploratory investigation. Journal of Managerial Issues, 161-177.

Davis, F.D. (1989). Perceived usefulness, perceived ease of use, and user acceptance of information technology. MIS Quarterly, 319-340. https://doi.org/10.2307/249008.

Ding, Z. (2017). Research on the Framework of Supply Chain Finance Operation Model of E-commerce Enterprises by Taking JD as An Example. Boletín Técnico, 55(15).

Dwivedi, Y.K., Janssen, M., Slade, E.L., Rana, N.P., Weerakkody, V., Millard, J., and Snijders, D. (2017). Driving innovation through big open linked data (BOLD): Exploring antecedents using interpretive structural modelling. Information Systems Frontiers, 19(2), 197-212.

https://doi.org/10.1007/s10796-016-9675-5.

Farrell, H. (2004). Trust, distrust, and power. Distrust, 85105.

Fairchild, A. (2005). Intelligent matching: integrating efficiencies in the financial supply chain. Supply Chain Management: An International Journal, 10(4), 244-248.

https://doi.org/10.1108/13598540510612703. 
Gelsomino, L. M., Mangiaracina, R., Perego, A., and Tumino, A. (2016). Supply chain finance: a literature review. International Journal of Physical Distribution \& Logistics Management, 46(4), 348-366. https://doi.org/10.1108/IJPDLM-08-2014-0173.

Global Supply Chain Finance Forum (n.d). In Brief Standard Definition. Global Supply Chain Forum. Available at: http://supplychainfinanceforum.org/ (20.06.2019).

Gomm, M.L. (2010). Supply chain finance: applying finance theory to supply chain management to enhance finance in supply chains. International Journal of Logistics: Research and Applications, 13(2), 133-142. https://doi.org/10.1080/13675560903555167.

Gynther, R.S. (1969). Some “conceptualizing” on goodwill. The Accounting Review, 44(2), 247-255.

Herath, G. (2015). Supply-chain finance: The emergence of a new competitive landscape. McKinsey.

Hofmann, E. (2005). Supply chain finance: some conceptual insights. Beiträge Zu Beschaffung Und Logistik, 203-214. https://doi.org/10.1007/978-3-322-82165-2_16.

Hofmann, E., and Belin, O. (2011). Supply chain finance solutions. Springer-Velag Berlin Heidelberg. https://doi.org/10.1007/978-3-642-17566-4.

Hofmann, E., and Kotzab, H. (2010). A supply chain-oriented approach of working capital management. Journal of Business Logistics, 31(2), 305-330. https://doi.org/10.1002/j.2158-1592.2010.tb00154.x.

Hofmann, E., Strewe, U.M., and Bosia, N. (2017). Supply chain finance and blockchain technology: the case of reverse securitization. Springer. https://doi.org/10.1007/978-3-319-62371-9.

Hofmann, E., and Zumsteg, S. (2015). Win-win and no-win situations in supply chain finance: the case of accounts receivable programs. Supply Chain Forum: An International Journal, 16(3), 30-50. https://doi.org/10.1080/16258312.2015.11716350.

Hudnurkar, M., Jakhar, S., and Rathod, U. (2014). Factors affecting collaboration in supply chain: a literature review. Procedia-Social and Behavioral Sciences, 133(1), 189-202. https://doi.org/10.1016/j.sbspro.2014.04.184.

Iacono, U.D., Reindorp, M., and Dellaert, N. (2015). Market adoption of reverse factoring. International Journal of Physical Distribution \& Logistics Management, 45(3), 286-308. https://doi.org/10.1108/IJPDLM-10-2013-0258.

Inkpen, A.C., and Currall, S.C. (2004). The coevolution of trust, control, and learning in joint ventures. Organization science, 15(5), 586-599. https://doi.org/10.1287/orsc.1040.0079.

Ivashina, V., and Scharfstein, D. (2010). Bank lending during the financial crisis of 2008. Journal of Financial Economics, 97(3), 319-338. https://doi.org/10.1016/j.jfineco.2009.12.001.

Jiang, J., Jin, Y., and Dong, C.Y. (2016). Research on the e-business logistics service mode based on branch storage and warehouse financing. International Journal of Services Technology and Management, 22(3-5), 203-217. https://doi.org/10.1504/IJSTM.2016.078537.

Kailash, Saha, R.K. and Goyal, S. (2019). Benchmarking of internal supply chain management: factors analysis and ranking using ISM approach and MICMAC analysis. International Journal of Productivity and Quality Management, 27(4), 394-419.

https://doi.org/10.1504/IJPQM.2019.101933.

Klapper, L. (2006). The role of factoring for financing small and medium enterprises. Journal of Banking and Finance, 30, 3111-3130. https://doi.org/10.1016/j.jbankfin.2006.05.001.

Lamoureux, J.F., and Evans, T.A. (2011). Supply chain finance: a new means to support the competitiveness and resilience of global value chains. https://doi.org/10.2139/ssrn.2179944.

Lee, J.D., and Gao, J. (2005, January). Trust, information technology, and cooperation in supply chains. Supply Chain Forum: An International Journal, 6(2), 82-89.

https://doi.org/10.1080/16258312.2005.11517150. 
Lee, J., Palekar, U.S., and Qualls, W. (2011). Supply chain efficiency and security: Coordination for collaborative investment in technology. European Journal of Operational Research, 210(3), 568-578. https://doi.org/10.1016/j.ejor.2010.10.015.

Lee, N., Sameen, H., and Cowling, M. (2015). Access to finance for innovative SMEs since the financial crisis. Research Policy, 44(2), 370-380. https://doi.org/10.1016/j.respol.2014.09.008.

Lee, H., and Whang, S. (2000). Information sharing in a supply chain. International Journal of Technology Management, 20(3/4), 373-387. https://doi.org/10.1504/IJTM.2000.002867.

Li, Y., Wang, S., Feng, G., and Lai, K.K. (2011). Comparative analysis of risk control in logistics and supply chain finance under different pledge fashions. International Journal of Revenue Management, 5(2-3), 121-144. https://doi.org/10.1504/IJRM.2011.040305.

Liebl, J., Hartmann, E., and Feisel, E. (2016). Reverse factoring in the supply chain: objectives, antecedents and implementation barriers. International Journal of Physical Distribution \& Logistics Management, 46(4), 393-413. https://doi.org/10.1108/IJPDLM-08-2014-0171.

Lotfi, Z., Mukhtar, M., Sahran, S., and Zadeh, A.T. (2013). Information sharing in supply chain management. Procedia Technology, 11, 298-304. https://doi.org/10.1016/j.protcy.2013.12.194.

Malone, D.W. (1975). An introduction to the application of interpretive structural modeling. Proceedings of the IEEE, 63(3), 397-404. https://doi.org/10.1109/PROC.1975.9765.

Maloni, M., and Benton, W.C. (2000). Power influences in the supply chain. Journal of Business Logistics, 21(1), 49-74.

Mandal, A., and Deshmukh, S.G. (1994). Vendor selection using interpretive structural modelling (ISM). International Journal of Operations \& Production Management, 14(6), 52-59. https://doi.org/10.1108/01443579410062086.

Marak, Z., and Pillai, D. (2019). Factors, outcome, and the solutions of supply chain finance: review and the future directions. Journal of Risk and Financial Management, 12(1), 3.

Martin, J. (2017). Suppliers' participation in supply chain finance practices: predictors and outcomes. International Journal of Integrated Supply Management, 11(2-3), 193-216. https://doi.org/10.1504/IJISM.2017.086242.

More, D., and Basu, P. (2013). Challenges of supply chain finance: A detailed study and a hierarchical model based on the experiences of an Indian firm. Business Process Management Journal, 19(4), 624-647. https://doi.org/10.1108/BPMJ-09-2012-0093.

Pellegrino, R., Costantino, N., and Tauro, D. (2019). Supply Chain Finance: A supply chain-oriented perspective to mitigate commodity risk and pricing volatility. Journal of Purchasing and Supply Management, 25(2), 118-133. https://doi.org/10.1016/j.pursup.2018.03.004.

Pfohl, H.C., Gallus, P., and Thomas, D. (2011). Interpretive structural modeling of supply chain risks. International Journal of Physical Distribution \& Logistics Management, 41(9), 839-859. https://doi.org/10.1108/09600031111175816.

Pfohl, H.C., and Gomm, M. (2009). Supply chain finance: optimizing financial flows in supply chains. Logistics Research, 1(3-4), 149-161. https://doi.org/10.1007/s12159-009-0020-y.

Popa, V. (2013). The financial supply chain management: a new solution for supply chain resilience. Amfiteatru Economic Journal, 15(33), 140-153.

Protopappa-Sieke, M., and Seifert, R.W. (2017). Benefits of working capital sharing in supply chains. Journal of the Operational Research Society, 68(5), 521-532. https://doi.org/10.1057/s41274-016-0009-2.

Randall, W.S., and Theodore Farris, M. (2009). Supply chain financing: using cash-to-cash variables to strengthen the supply chain. International Journal of Physical Distribution \& Logistics Management, 39(8), 669-689. https://doi.org/10.1108/09600030910996314. 
Roberts, S. (2003). Supply chain specific? Understanding the patchy success of ethical sourcing initiatives. Journal of Business Ethics, 44(2-3), 159-170. https://doi.org/10.1023/A:1023395631811.

Rogers, E.M. (2010). Diffusion of innovations. Simon and Schuster.

Saxena, J.P., Sushil., and Vrat, P. (1990). Impact of indirect relationships in classification of variables - a micmac analysis for energy conservation. Systems Research, 7(4), 245-253. https://doi.org/10.1002/sres.3850070404.

Shankar, R., Gupta, R., and Pathak, D.K. (2018). Modeling critical success factors of traceability for food logistics system. Transportation Research Part E: Logistics and Transportation Review, 119, 205-222. https://doi.org/10.1016/j.tre.2018.03.006.

Shinozaki, S. (2014). A new regime of SME finance in emerging Asia: Enhancing access to growth capital and policy implications. Journal of International Commerce, Economics and Policy, 5(03), 1440010. https://doi.org/10.1142/S1793993314400109.

Silvestro, R., and Lustrato, P. (2014). Integrating financial and physical supply chains: the role of banks in enabling supply chain integration. International Journal of Operations \& Production Management, 34(3), 298-324. https://doi.org/10.1108/IJOPM-04-2012-0131.

Simatupang, T.M., Wright, A.C., and Sridharan, R. (2004). Applying the theory of constraints to supply chain collaboration. Supply Chain Management: An International Journal. https://doi.org/10.1108/13598540410517584.

Singh, R.K., Garg, S.K., and Deshmukh, S.G. (2007). Interpretive structural modelling of factors for improving competitiveness of SMEs. International Journal of Productivity and Quality Management, 2(4), 423-440. https://doi.org/10.1504/IJPQM.2007.013336.

Sommer, M., and O’Kelly, R. (2017). Supply Chain Finance: Riding the Waves. Oliver Wyman.

Sopranzetti, B.J. (1998). The economics of factoring accounts receivable. Journal of Economics and Business, 50(4), 339-359. https://doi.org/10.1016/S0148-6195(98)00008-3.

Soufani, K. (2002). The decision to finance account receivables: the factoring option. Managerial and Decision Economics, 23(1), 21-32. https://doi.org/10.1002/mde.1046.

Wandfluh, M., Hofmann, E., and Schoensleben, P. (2015). Financing buyer-supplier dyads: an empirical analysis on financial collaboration in the supply chain. International Journal of Logistics Research and Applications, 19(3), 200-217. https://doi.org/10.1080/13675567.2015.1065803.

Wuttke, D.A., Blome, C., and Henke, M. (2013a). Focusing the financial flow of supply chains: An empirical investigation of financial supply chain management. International Journal of Production Economics, 145(2), 773-789. https://doi.org/10.1016/j.ijpe.2013.05.031.

Wuttke, D.A., Blome, C., Foerstl, K., and Henke, M. (2013b). Managing the innovation adoption of supply chain finance - Empirical evidence from six European case studies. Journal of Business Logistics, 34(2),148-166. https://doi.org/10.1111/jbl.12016.

Wuttke, D.A., Blome, C., Heese, H.S., and Protopappa-Sieke, M. (2016). Supply chain finance: Optimal introduction and adoption decisions. International Journal of Production Economics, 178, 72-81. https://doi.org/10.1016/j.ijpe.2016.05.003.

Wuttke, D.A., Rosenzweig, E.D., and Heese, H.S. (2019). An empirical analysis of supply chain finance adoption. Journal of Operations Management, 65(3), 242-261. https://doi.org/10.1002/joom.1023.

Xiao, Y., and Zhang, J. (2017). Preselling to a retailer with cash flow shortage on the manufacturer. Omega, 80, 43-57. https://doi.org/10.1016/j.omega.2017.09.004.

Xu, X., Chen, X., Jia, F., Brown, S., Gong, Y., and Xu, Y. (2018). Supply chain finance: A systematic literature review and bibliometric analysis. International Journal of Production Economics, 204, 160-173. https://doi.org/10.1016/j.ijpe.2018.08.003. 
Yan, N., Dai, H., and Sun, B. (2014). Optimal bi-level Stackelberg strategies for supply chain financing with both capital-constrained buyers and sellers. Applied Stochastic Models in Business and Industry, 30(6), 783-796. https://doi.org/10.1002/asmb.2021.

Ye, Fei, and Zhang, C. (2010). Impact of resource dependence, trust and relationship commitment among supply chain partners on information system alignment. Industrial Engineering and Management, 15(6), 7-15.

Yu, J., and Zhu, D. (2018). Study on the Selection Strategy of Supply Chain Financing Modes Based on the Retailer's Trade Grade. Sustainability, 10(9), 3045. https://doi.org/10.3390/su10093045.

Zhang, C. (2016). Small and medium-sized enterprises closed-loop supply chain finance risk based on evolutionary game theory and system dynamics. Journal of Shanghai Jiaotong University (Science), 21(3), 355-364. https://doi.org/10.1007/s12204-016-1733-0.

Zhang, M., and Huo, B. (2013). The impact of dependence and trust on supply chain integration. International Journal of Physical Distribution \& Logistics Management. https://doi.org/10.1108/IJPDLM-10-2011-0171.

Zheng, J., and Zhang, J. (2017). 18. Analysis on Coordination Mechanism of Supply Chain Finance for B2C Cross-border Ecommerce. Revista de la Facultad de Ingeniería, 32(14), 103-109.

Zhou, Q., Chen, X., and Li, S. (2018). Innovative financial approach for agricultural sustainability: A case study of Alibaba. Sustainability, 10(3), 891. https://doi.org/10.3390/su10030891. 